\title{
UCRL-TR-224775
}

LA WAENCE LIVIFINOAE MATIONAL LADOAMTORY

\section{LLNL Site 200 Risk Management Plan}

D. M. Pinkston,

M. A. Johnson

S. W. Fong

September 2006 


\section{Auspices Statement}

This work was performed under the auspices of the U.S. Department of Energy by University of California, Lawrence Livermore National Laboratory under Contract W-7405-Eng-48.

\section{Disclaimer}

This document was prepared as an account of work sponsored by an agency of the United States Government. Neither the United States Government nor the University of California nor any of their employees, makes any warranty, express or implied, or assumes any legal liability or responsibility for the accuracy, completeness, or usefulness of any information, apparatus, product, or process disclosed, or represents that its use would not infringe privately owned rights. Reference herein to any specific commercial product, process, or service by trade name, trademark, manufacturer, or otherwise, does not necessarily constitute or imply its endorsement, recommendation, or favoring by the United States Government or the University of California. The views and opinions of authors expressed herein do not necessarily state or reflect those of the United States Government or the University of California, and shall not be used for advertising or product endorsement purposes 


\section{CERTIFICATION LETTER}

\section{Certification Statement for Program 1 Processes}

Based on the criteria in Section 2735.4 of Title 19 of CCR, the distance to the specified endpoint for the worst-case accidental release scenario for the following processes is less than the distance to the nearest public receptor:

- Process 1: Lithium Hydride A

- Process 2: Lithium Hydride B

- Process 3: Lithium Hydride C

- Process 4: Lithium Hydride D

- Process 5: Lithium Hydride $\mathrm{E}$

- Process 6: Lithium Hydride F

- Process 7: Nitric Acid A

[Sections $1.17 \& 2.0$ provide chemical inventories \& distance to nearest public receptor for each of the above processes.]

Within the past five years, these processes have had no accidental release that caused offsite impacts provided in the risk management program Section 2735.4 (c)(1). No additional measures are necessary to prevent offsite impacts from accidental releases. In the event of fire, explosion, or a release of a regulated substance from the processes, entry within the distance to the specified endpoints may pose a danger to public emergency responders. Therefore, public emergency responders should not enter this area except as arranged with the emergency contact indicated in the RMP. The undersigned certifies that, to the best of my knowledge, information, and belief, formed after reasonable inquiry, the information submitted is true, accurate, and complete.

\section{Reviewed By:}

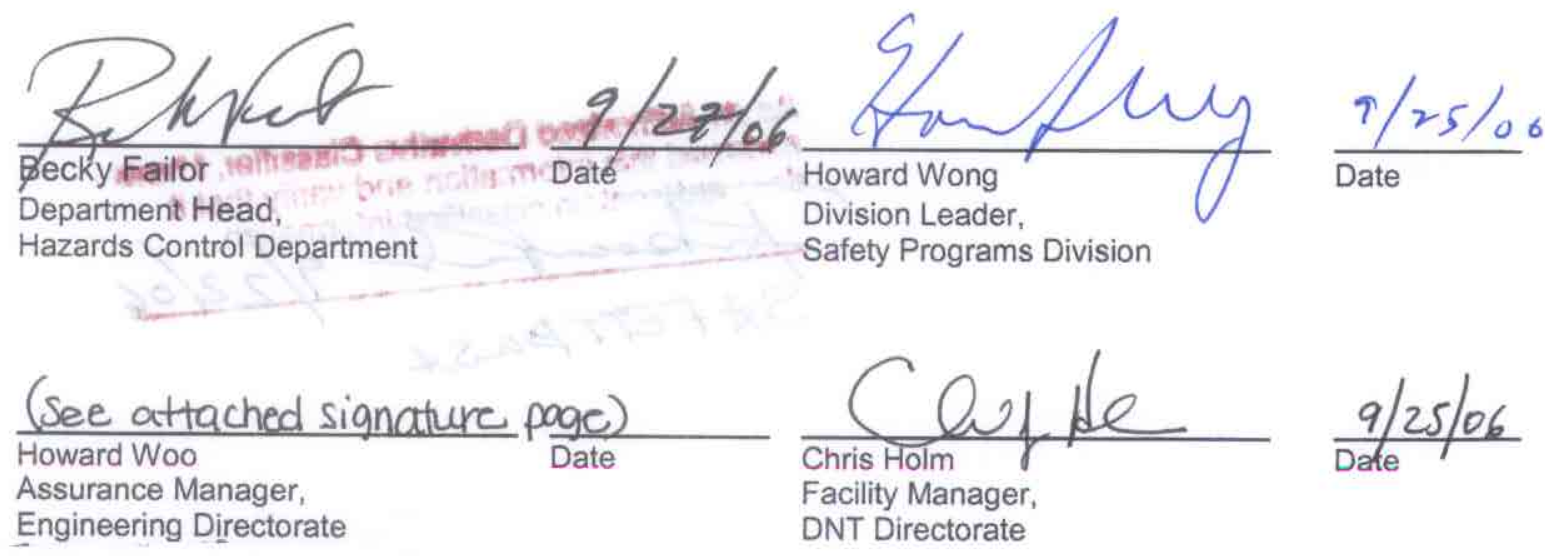


Daud Rinlistia David Pinkston Section Leader, Authorization Basis

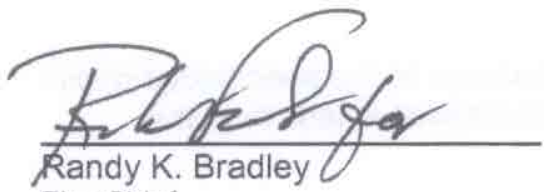

Fire Chief,

LLNL
9/20106

Date

Kathyrn A. Rauhut Laboratory Counsel,

LLNL

\section{Approved By:}

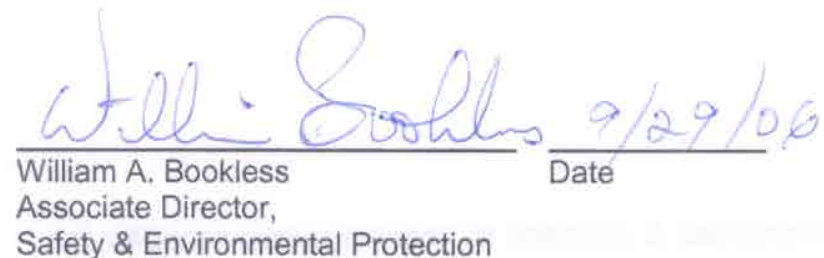

Safety \& Environmental Protection

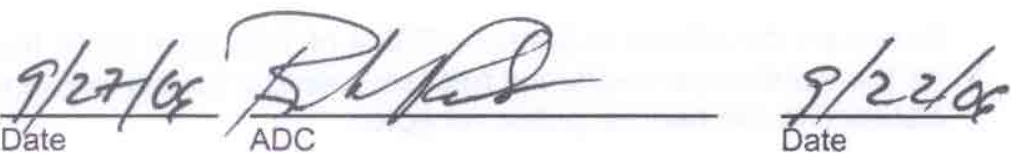
Date 


\section{CERTIFICATION LETTER}

\section{Certification Statement for Program 1 Processes}

Based on the criteria in Section 2735.4 of Title 19 of CCR, the distance to the specified endpoint for the worst-case accidental release scenario for the following processes is less than the distance to the nearest public receptor:

- Process 1: Lithium Hydride A

- Process 2: Lithium Hydride B

- Process 3: Lithium Hydride C

- Process 4: Lithium Hydride D

- Process 5: Lithium Hydride E

- Process 6: Lithium Hydride F

- Process 7: Nitric Acid A

[Sections $1.17 \& 2.0$ provide chemical inventories \& distance to nearest public receptor for each of the above processes.]

Within the past five years, these processes have had no accidental release that caused offsite impacts provided in the risk management program Section 2735.4 (c)(1). No additional measures are necessary to prevent offsite impacts from accidental releases. In the event of fire, explosion, or a release of a regulated substance from the processes, entry within the distance to the specified endpoints may pose a danger to public emergency responders. Therefore, public emergency responders should not enter this area except as arranged with the emergency contact indicated in the RMP. The undersigned certifies that, to the best of my knowledge, information, and belief, formed after reasonable inquiry, the information submitted is true, accurate, and complete.

\section{Reviewed By:}
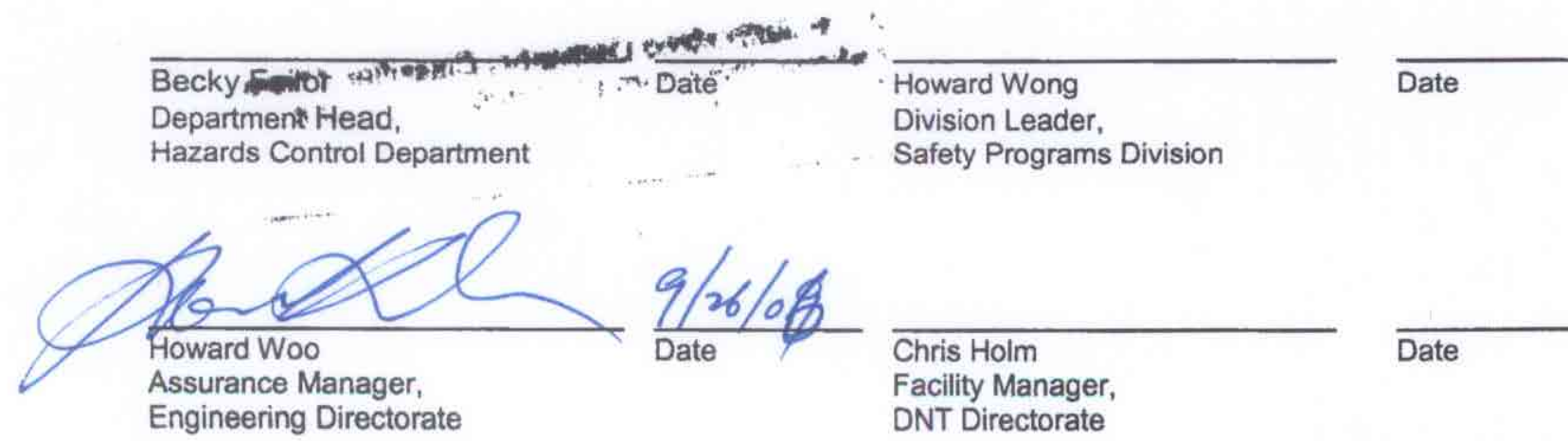

Chris Holm

Facility Manager,

Date

Engineering Directorate

DNT Directorate 


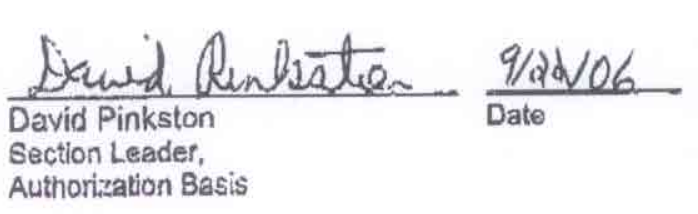

Randy K, Eradley

Fire Chief,

LLNL

Approved By:

William A. Bookless

Assaciate Director.

Safety \& Environmental Protection
Date

\section{Date}

ADC

Date

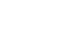
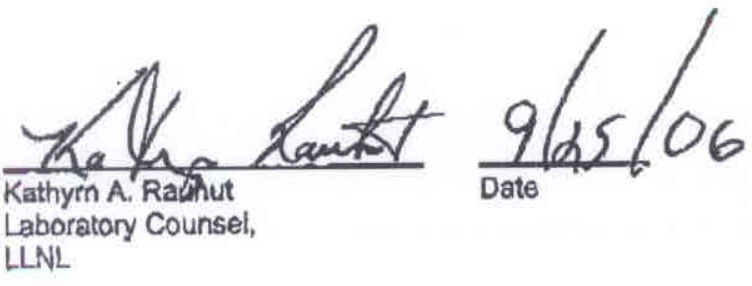

Date

Laboratory Counsel 


\section{RMP Report for Lawrence Livermore National Laboratory Site 200 \\ Section 1. Registration Information}

1.1 Source Identification: $\quad$ Facility ID: 1 There were no reportable accidents in the last 5 years.
a. Facility Name: Lawrence Livermore National Laboratory Site 200
b. Parent Company \#1 Name:
c. Parent Company \#2 Name:

1.2 EPA Facility Identifier:

1.3 Other EPA Systems Facility ID: $\quad$ CA2890012584

1.4 Dun and Bradstreet Numbers (DUNS):
a. Facility DUNS:
b. Parent Company \#1 DUNS:
962973731
c. Parent Company \#2 DUNS:

1.5 Facility Location Address:
a. Street 1: $\quad 7000$ East Ave
$\begin{array}{ll}\text { b. Street 2: } & \text { P.O. Box 808, L-668 }\end{array}$
c. City: Livermore
d. State: $C A$
e. Zip: $94550-0808$
f. County: Alameda

Facility Latitude and Longitude:
g. Lat. (dd.dddddd):
37.686389
h. Long. (ddd.dddddd):
$-121.706111$
i. Lat/Long Method:
11
Interpolation - Map
j. Lat/Long Description: FC
Facility Centroid
k. Horizontal accuracy measure (m): 25
I. Horizontal Reference Datum Code: 002
North American Datum of 1983
m. Source Map Scale Number:
24000

1.6 Owner or Operator:

a. Name: US Department of Energy

b. Phone: (925) 422-3343

Mailing address:
$\begin{array}{ll}\text { c. Street 1: } & \text { P.O. Box } 808\end{array}$
d. Street 2:
e. City: Livermore
f. State: $C A$
g. Zip: $\quad 94550-0808$ 
1.7 Name and title of person or position responsible for part 68 (RMP) implementation:
a. Name of person:
William Bookless
b. Title of person or position:
Associate. Director, Safety \& Environmental Protection
c. Email address:

1.8 Emergency contact:
a. Name: Randy Bradley
b. Title: $\quad$ LLNL Fire Chief
$\begin{array}{ll}\text { c. Phone: } & (925) 423-1800\end{array}$
d. 24-hour phone: (925) 422-7595
e. Ext. or PIN:
f. Email address: bradley7@llnl.gov

1.9 Other points of contact:

a. Facility or Parent Company E-Mail Address: pao@llnl.gov (Public Affairs)

b. Facility Public Contact Phone: $\quad$ (925) 422-4599 (Public Affairs)

c. Facility or Parent Company WWW Homepage Address: www.Ilnl.gov

1.10 LEPC:

1.11 Number of full time employees on site: $\quad 10,360$

1.12 Covered by:
a. OSHA PSM: Yes
b. EPCRA 302: Yes
c. CAA Title V: No

Air operating permit ID:

1.13 OSHA Star or Merit Ranking: No

1.14 Last Safety Inspection (by an External Agency) Date: $\quad$ 06/01/2005

1.15 Last Safety Inspection Performed by an External Agency: EPA

1.16 Will this RMP involve predictive filing?: No

1.18 RMP Preparer Information:
a. Name:
b. Telephone:
c. Street1:
d. Street2: 
e. City:
f. State:
g. ZIP:

\section{Section 1.17 Process(es)}
a. Process ID: 1 Program Level $1 \quad$ Lithium Hydride A
b. NAICS Code
54171 Research and Development in the Physical, Engineering, and Life Sciences
c. Process Chemicals
c.1 Process Chemical (ID / Name)
c.2 CAS Nr.
c.3 Qty (Ibs.)
1 Lithium Hydride
7580-67-8
$1,102(T Q=100)$

\section{a. Process ID: $\underline{2}$ Program Level $1 \quad$ Lithium Hydride B \\ b. NAICS Code}

54171 Research and Development in the Physical, Engineering, and Life Sciences

c. Process Chemicals

c.1 Process Chemical (ID / Name)

2 Lithium Hydride c.2 CAS Nr.

7580-67-8 c.3 Qty (Ibs.)

$1,543(\mathrm{TQ}=100)$

\section{a. Process ID: $\underline{3} \quad$ Program Level $1 \quad$ Lithium Hydride C}

54171 Research and Development in the Physical, Engineering, and Life Sciences c. Process Chemicals

c.1 Process Chemical (ID / Name)

c. 2 CAS Nr.

c.3 Qty (Ibs.)

3 Lithium Hydride

7580-67-8

$3,527(\mathrm{TQ}=100)$

\section{a. Process ID: $4 \quad$ Program Level $1 \quad$ Lithium Hydride D}

54171 Research and Development in the Physical, Engineering, and Life Sciences c. Process Chemicals

c. 1 Process Chemical (ID / Name)

4 Lithium Hydride c.2 CAS Nr.

7580-67-8 c.3 Qty (lbs.)

$3,527(\mathrm{TQ}=100)$

\section{a. Process ID: $\underline{5} \quad$ Program Level $1 \quad$ Lithium Hydride E}

54171 Research and Development in the Physical, Engineering, and Life Sciences c. Process Chemicals

c.1 Process Chemical (ID / Name)

5 Lithium Hydride c.2 CAS Nr.

7580-67-8 c.3 Qty (Ibs.)

$110(T Q=100)$

\section{a. Process ID: $\underline{6}$ Program Level $1 \quad$ Lithium Hydride F}

54171 Research and Development in the Physical, Engineering, and Life Sciences c. Process Chemicals

c.1 Process Chemical (ID / Name)

6 Lithium Hydride c.2 CAS Nr.

7580-67-8 c.3 Qty (Ibs.)

$441(T Q=100)$ 


\section{a. Process ID: $\underline{7}$ Program Level $1 \quad$ Nitric Acid A}

\section{b. NAICS Code}

54171 Research and Development in the Physical, Engineering, and Life Sciences

c. Process Chemicals
c.1 Process Chemical (ID / Name)
c.2 CAS Nr.
c.3 Qty (Ibs.)
$7 \quad$ Nitric acid
7697-37-2
$9,600(T Q=1,000)$

\section{Section 2. Toxics: Worst Case}

\section{Toxics: Worst Case ID 1}

2.1 a. Chemical Name: Lithium Hydroxide

b. Percent Weight of Chemical (if in a mixture):

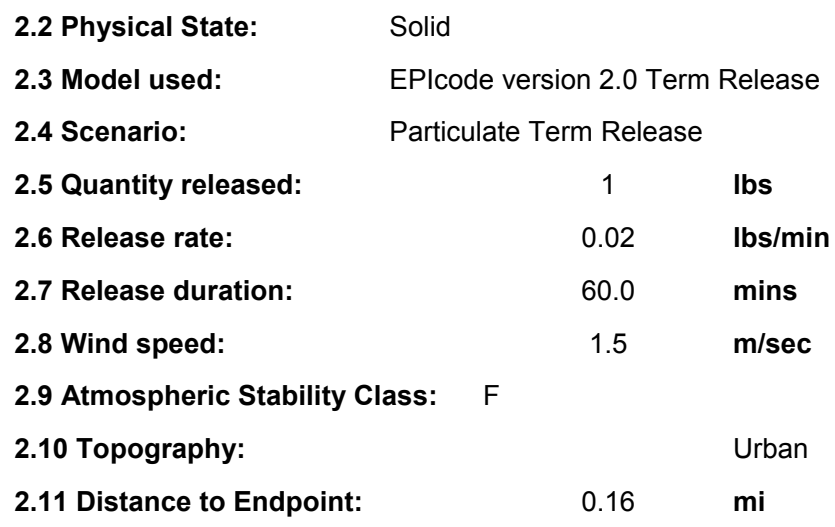

2.12 Estimated Residential population within distance to endpoint ( $>0.25$ miles to nearest public receptor)

2.13 Public receptors within distance to endpoint:
a. Schools: No
d. Prisons/Correction facilities:
No
b. Residences: No
e. Recreation areas:
No
c. Hospitals: No
f. Major commercial, office or, industrial areas: No
g. Other (Specify):

2.14 Environmental receptors within distance to endpoint:
a. National or state parks, forests, or monuments:
No
b. Officially designated wildlife sanctuaries, preserves, or refuges:
No
c. Federal wilderness areas:
No
d. Other (Specify):

2.15 Passive mitigation considered:
a. Dikes:
No
d. Drains:
No
b. Enclosures:
e. Sumps:
No
c. Berms:
No
f. Other (Specify:

2.16 Graphic file name: 


\section{Toxics: Worst Case ID $\underline{2}$}

2.1 a. Chemical Name: Lithium Hydroxide

b. Percent Weight of Chemical (if in a mixture):

2.2 Physical State: Solid

2.3 Model used:

EPIcode version 2.0 Term Release

2.4 Scenario:

Particulate Term Release

2.5 Quantity released:

$\begin{array}{cl}1.5 & \text { lbs } \\ 0.03 & \text { Ibs/min } \\ 60.0 & \text { mins } \\ 1.5 & \mathrm{~m} / \mathrm{sec}\end{array}$

2.8 Wind speed:

$1.5 \mathrm{~m} / \mathrm{sec}$

2.9 Atmospheric Stability Class: $F$

2.10 Topography:

Urban

2.11 Distance to Endpoint:

$0.18 \quad \mathrm{mi}$

(>0.37 miles to nearest public receptor)

2.12 Estimated Residential population within distance to endpoint:

0

2.13 Public receptors within distance to endpoint:
a. Schools:
d. Prisons/Correction facilities:
No
b. Residences: No
e. Recreation areas:
No
c. Hospitals: No
f. Major commercial, office or, industrial areas: No
g. Other (Specify):

2.14 Environmental receptors within distance to endpoint:
a. National or state parks, forests, or monuments:
No
b. Officially designated wildlife sanctuaries, preserves, or refuges:
No
c. Federal wilderness areas:
No
d. Other (Specify):

2.15 Passive mitigation considered:
a. Dikes:
No
d. Drains:
No
b. Enclosures:
e. Sumps:
No
c. Berms:
No
f. Other (Specify:

2.16 Graphic file name:

\section{Toxics: Worst Case ID $\underline{3}$}

2.1 a. Chemical Name: Lithium Hydroxide

b. Percent Weight of Chemical (if in a mixture):

2.2 Physical State: Solid

2.3 Model used:

EPIcode version 2.0 Term Release

2.4 Scenario:

Particulate Term Release

2.5 Quantity released:

$\begin{array}{cl}3.5 & \text { lbs } \\ 0.06 & \text { Ibs } / \mathrm{min} \\ 60.0 & \text { mins } \\ 1.5 & \mathrm{~m} / \mathrm{sec}\end{array}$

2.8 Wind speed:

$1.5 \mathrm{~m} / \mathrm{sec}$

2.9 Atmospheric Stability Class: F 
2.10 Topography:

Urban

2.11 Distance to Endpoint:

$0.29 \quad \mathrm{mi}$

2.12 Estimated Residential population within distance to endpoint:

0

2.13 Public receptors within distance to endpoint:
a. Schools:
d. Prisons/Correction facilities:
No
b. Residences: No
e. Recreation areas:
No
c. Hospitals: No
f. Major commercial, office or, industrial areas: No
g. Other (Specify):

2.14 Environmental receptors within distance to endpoint:
a. National or state parks, forests, or monuments:
No
b. Officially designated wildlife sanctuaries, preserves, or refuges:
No
c. Federal wilderness areas:
No
d. Other (Specify):

2.15 Passive mitigation considered:
a. Dikes:
No
d. Drains:
No
b. Enclosures: No
e. Sumps:
No
c. Berms:
No
f. Other (Specify:

2.16 Graphic file name:

\section{Toxics: Worst Case ID 4}

2.1 a. Chemical Name: Lithium Hydroxide

b. Percent Weight of Chemical (if in a mixture):

2.2 Physical State: Solid

2.3 Model used:

EPIcode version 2.0 Term Release

2.4 Scenario:

Particulate Term Release

2.5 Quantity released:

2.6 Release rate:

2.7 Release duration:

2.8 Wind speed:

$\begin{array}{cl}3.5 & \text { lbs } \\ 0.06 & \text { lbs } / \mathrm{min} \\ 60.0 & \mathrm{mins} \\ 1.5 & \mathrm{~m} / \mathrm{sec}\end{array}$

Urban

$0.29 \quad \mathbf{m i}$

2.10 Topography:

$\mathrm{F}$

2.11 Distance to Endpoint:

( $>0.37$ miles to nearest public receptor)

2.12 Estimated Residential population within distance to endpoint:

0

2.13 Public receptors within distance to endpoint:
a. Schools:
d. Prisons/Correction facilities:
No
b. Residences: No
e. Recreation areas:
No
c. Hospitals: No
f. Major commercial, office or, industrial areas: No
g. Other (Specify):

2.14 Environmental receptors within distance to endpoint:

a. National or state parks, forests, or monuments:

No

b. Officially designated wildlife sanctuaries, preserves, or refuges:

No

c. Federal wilderness areas:

No

d. Other (Specify): 
2.15 Passive mitigation considered:
a. Dikes:
No
d. Drains:
No
b. Enclosures:
No
e. Sumps:
No
c. Berms:
No
f. Other (Specify:

2.16 Graphic file name:

\section{Toxics: Worst Case ID $\underline{\mathbf{5}}$}

2.1 a. Chemical Name: Lithium Hydroxide

b. Percent Weight of Chemical (if in a mixture):

2.2 Physical State: Solid

2.3 Model used: $\quad$ EPIcode version 2.0 Term Release

2.4 Scenario:

Particulate Term Release

2.5 Quantity released:

$0.1 \quad$ lbs

2.6 Release rate:

$0.002 \quad \mathrm{lbs} / \mathrm{min}$

2.7 Release duration:

$60.0 \quad$ mins

2.8 Wind speed:

$1.5 \mathrm{~m} / \mathrm{sec}$

2.9 Atmospheric Stability Class: F

2.10 Topography:

Urban

2.11 Distance to Endpoint:

$0.05 \quad$ mi

( $>0.37$ miles to nearest public receptor)

2.12 Estimated Residential population within distance to endpoint:

0

2.13 Public receptors within distance to endpoint:
a. Schools: No
d. Prisons/Correction facilities:
No
b. Residences: No
e. Recreation areas:
No
c. Hospitals: No
f. Major commercial, office or, industrial areas: No
g. Other (Specify):

2.14 Environmental receptors within distance to endpoint:
a. National or state parks, forests, or monuments:
No
b. Officially designated wildlife sanctuaries, preserves, or refuges:
No
c. Federal wilderness areas:
No
d. Other (Specify):

2.15 Passive mitigation considered:
a. Dikes:
No
d. Drains:
No
b. Enclosures:
e. Sumps:
No
c. Berms:
No
f. Other (Specify:

2.16 Graphic file name:

\section{Toxics: Worst Case ID $\underline{6}$}

2.1 a. Chemical Name: Lithium Hydroxide

b. Percent Weight of Chemical (if in a mixture):

2.2 Physical State:

Solid

2.3 Model used:

EPIcode version 2.0 Term Release

2.4 Scenario:

Particulate Term Release

2.5 Quantity released:

$0.4 \quad$ Ibs 
2.6 Release rate:

2.7 Release duration:

2.8 Wind speed:

2.9 Atmospheric Stability Class: F

2.10 Topography:

2.11 Distance to Endpoint:

2.12 Estimated Residential population within distance to endpoint:

Ibs/min

$60.0 \quad$ mins

$1.5 \mathrm{~m} / \mathrm{sec}$

2.13 Public receptors within distance to endpoint:
a. Schools:
No
d. Prisons/Correction facilities:
No
b. Residences: No
e. Recreation areas:
No
c. Hospitals: No
f. Major commercial, office or, industrial areas: No
g. Other (Specify):

2.14 Environmental receptors within distance to endpoint:

a. National or state parks, forests, or monuments:

No

b. Officially designated wildlife sanctuaries, preserves, or refuges:

No

c. Federal wilderness areas:

No

d. Other (Specify):

2.15 Passive mitigation considered:
a. Dikes:
No
d. Drains:
No
b. Enclosures: No
e. Sumps:
No
c. Berms:
No
f. Other (Specify:

2.16 Graphic file name:

\section{Toxics: Worst Case ID 7}

2.1 a. Chemical Name: Nitric Acid

b. Percent Weight of Chemical (if in a mixture):

2.2 Physical State: Liquid

2.3 Model used: $\quad$ EPA's OCA Guidance Reference Tables or Equations

2.4 Scenario:

Liquid Release Evaporative Model

2.5 Quantity released:

$\begin{array}{cl}24 & \text { lbs } \\ 2.4 & \text { Ibs/min } \\ 10.0 & \text { mins } \\ 1.5 & \mathrm{~m} / \mathrm{sec}\end{array}$

2.6 Release rate:

2.8 Wind speed:

2.10 Topography:

Urban

2.11 Distance to Endpoint:

$0.3 \quad \mathbf{m i}$

( $>0.37$ miles to nearest public receptor)

2.12 Estimated Residential population within distance to endpoint:

0

2.13 Public receptors within distance to endpoint:
a. Schools: No
d. Prisons/Correction facilities:
No
b. Residences: No
e. Recreation areas:
No
c. Hospitals: No
f. Major commercial, office or, industrial areas: No
g. Other (Specify):

2.14 Environmental receptors within distance to endpoint: 

a. National or state parks, forests, or monuments:
b. Officially designated wildlife sanctuaries, preserves, or refuges:
No
c. Federal wilderness areas:
d. Other (Specify):

2.15 Passive mitigation considered:
a. Dikes:
No
d. Drains:
No
b. Enclosures:
No
e. Sumps:
No
c. Berms:
No
f. Other (Specify:

2.16 Graphic file name:

\section{Section 3. Toxics: Alternative Release --- No Data To Report \\ Section 4. Flammables: Worst Case --- No Data To Report \\ Section 5. Flammables: Alternative Release --- No Data To Report}

Section 6. Accident History --- There were no reportable accidents in the last 5 years.

\section{Section 7. Prevention Program 3 --- No Data To Report}

\section{Section 8. Prevention Program 2 --- No Data To Report}

\section{Section 9. Emergency Response}

9.1 Written Emergency Response (ER) Plan:

a. Is facility included in written community emergency response plan?

b. Does facility have its own written emergency response plan? Yes

9.2 Does facility's ER plan include specific actions to be taken in response to accidental releases of regulated substance(s)?

9.3 Does facility's ER plan include procedures for informing the public and local agencies responding to accidental releases?

9.4 Does facility's ER plan include information on emergency heath care?

9.5 Date of most recent review or update of facility's ER plan:

9.7 Local agency with which facility's ER plan or response activities are coordinated:
a. Name of agency:
Office of Emergency Services
b. Telephone number:
(925) 803-7800

9.8 Subject to:

a. OSHA Regulations at 29 CFR 1910.38:

b. OSHA Regulations at 29 CFR 1910.120: 
Facility Name: Lawrence Livermore National Laboratory Site 200

EPA ID: CA2890012584

d. RCRA Regulations at 40 CFR 264, 265, and 279.52:

Yes

e. OPA-90 Regulations at 40 CFR 112, 33 CFR 154, 49 CFR 194, or 30 CFR 254:

No

f. State EPCRA Rules/Law:

No

g. Other (Specify):

DOE Order 151.1, Comprehensive Emergency Management System 


\section{Executive Summary}

\section{A. Accidental Release Prevention and Emergency Response Policies}

It is the Lawrence Livermore National Laboratory's (LLNL) policy to perform work in a manner that protects the health and safety of employees and the public, preserves the quality of the environment, and prevents property damage using the Integrated Safety Management System. The environment, safety, and health are to take priority in the planning and execution of work activities at the Laboratory. Furthermore, it is the policy of LLNL to comply with applicable ES\&H laws, regulations, and requirements identified in approved work smart standards (LLNL Environment, Safety and Health Manual, Document 1.2, ES\&H Policies of LLNL). The program and policies that improve LLNL's ability to prevent or mitigate accidental releases are described in the LLNL Environment, Health, and Safety Manual that is available to the public at http://www.llnl.gov/es and h/esh-manual.html.

The laboratory uses an emergency management system known as the Incident Command System, in accordance with the California Standardized Emergency Management System (SEMS) to respond to Operational Emergencies and to mitigate consequences resulting from them. Operational Emergencies are defined as unplanned, significant events or conditions that require time-urgent response from outside the immediate area of the incident that could seriously impact the safety or security of the public, LLNL's employees, its facilities, or the environment. The Emergency Plan contains LLNL's Operational Emergency response policies, commitments, and institutional responsibilities for managing and recovering from emergencies. It is not possible to list in the Emergency Plan all events that could occur during any given emergency situation. However, a combination of hazard assessments, an effective Emergency Plan, and Emergency Plan Implementing Procedures (EPIPs) can provide the framework for responses to postulated emergency situations. Revision 7, 2004 of the above mentioned LLNL Emergency Plan is available to the public at http://www.IInl.gov/es and h/sourcematerial/ucrl ma 113311 r7.pdf. The most recent revision of the LLNL Emergency PlanUCRL-AM-218588, Revision 9, January 2006, has been included as an appendix to the RMP Supplemental Information document.

\section{B. Facility Description and Regulated Substances Handled}

LLNL's Livermore Site (Site 200) is located at 7000 East Avenue, about 40 miles east of San Francisco, at the southeast end of the Livermore Valley in southeastern Alameda County. The city of Livermore's central business district is located about 3 miles west of the site. LLNL Site 200 is owned by the Department of Energy, National Nuclear Security Administration and operated by the University of California.

Owner Information

Camille Yaun-Soo Hoo

(925) 422-2572

National Nuclear Security Administration

Livermore Site Office

P.O. Box 808, L-293

Livermore, CA 94551-0808

Operator Information

William A. Bookless, Associate Director for Safety and Environmental Protection

(925) 422-3343

P.O. Box 808, L-668

Livermore, CA 94551-0808

Facility Contact

William A. Bookless, Associate Director for Safety and Environmental Protection 
(925) 422-3343

P.O. Box 808 , L-668

Livermore, CA 94551-0808

LLNL Site 200 is a research and development laboratory with infrastructure necessary to support its operations and personnel. Research and development activities at LLNL are focused on stockpile stewardship; achieving robust and vital scientific, engineering, and manufacturing capability; inertial confinement fusion; laser technology; materials and process science; computational and information sciences; basic sciences; engineering sciences; and biological sciences.

Based upon CalARP Program regulations, guidance found in California Accidental Release Prevention Program (CalARP) Administering Guidance, Chapter 1, a review of facility specific documents, accident analyses summarized in this document \& detailed in the LLNL Site 200 RMP Supporting Information document, LLNL has determined that each process meeting the CalARP threshold criteria meets the requirements for CalARP Program Level 1.

In accordance with CalARP regulations, LLNL considers the natural segmentation of processes at Site 200 to be on a building basis and therefore consideration of inventory should be on a building basis rather than a "site-wide" basis. Only those materials identified as equal to as or greater than the threshold quantities for the CalARP program on a building (process) level are reflected in this document. As such, materials and quantities reported in this document on a building (process) level will vary from materials and quantities reported in the LLNL Hazardous Materials Business Plan, Acutely Hazardous Material Registration Form on a site-wide level.

For each of the six process involving regulated quantities of lithium hydride, worst case accident analysis shows that the toxic endpoint lies within the site boundaries. These analyses document that the nearest public receptor is beyond the distance to a toxic or flammable endpoint. Refer to the LLNL Site 200 RMP Supporting Information document for a more detailed explanation of the worst case accident analyses for these processes.

For the process involving regulated quantities of nitric acid, worst case accident analysis predicts a hazard zone well within areas under the jurisdiction of the Department of Energy. This analysis documents that the nearest public receptor is beyond the distance to a toxic or flammable endpoint. Refer to the LLNL Site 200 RMP Supporting Information document for a more detailed explanation of the worst case accident analysis for this process.

\section{General Accidental Release Prevention Program and Chemical-Specific Prevention Steps}

LLNL maintains an active program to protect workers, the public, and the environment from harm resulting from its activities. Its policies and technical directions for controlling all hazards that are present as a result of its operations are described in the LLNL Environment, Health, and Safety Manual (referenced above). Applicable sections of this manual concern inspection and maintenance of pressure systems, health hazard awareness, handling toxic materials, personal protective equipment, and emergency response. Plans and procedures are developed for operations handling toxic materials. Operation specific training (both classroom and on the job) are provided as well as health hazard awareness, and hazardous material response training provided to LLNL emergency responders. The LLNL Fire Chief is a California Fire Chief and is empowered, as are other California Fire Chiefs, to direct public response to emergency events. The LLNL firefighters are the first responders to local fires and to hazardous material spills in the Livermore Valley in agreement with local agencies.

D. Five-Year Accident History 
Based upon review of site accident records, within the past five years, LLNL Site 200 has not had an accidental release involving CalARP Program regulated substances lithium hydride or nitric acid where exposure to the substance, its reaction products, overpressure generated by an explosion involving the substance, or radiant heat generated by a fire involving the substance has led to offsite deaths, injuries, or response or restoration activities for an exposure of an environmental receptor.

\section{E. Emergency Response Program}

LLNL's Emergency Response Organization within the Hazards Control Department is responsible for emergency response planning. Their responsibilities include:

- Interaction with NNSA/DOE on emergency planning issues,

- Coordination of emergency response planning with LLNL's Security Department, Public Affairs Office, and off-site entities.

- Providing guidance to LLNL program and facility operations, develops and implements emergency response drills, operates LLNL's Emergency Operations Center,

- Oversight of the various LLNL Operations Support Centers,

- Preparation and maintenance of emergency preparedness program documents,

- Implementation of the LLNL Emergency Duty Officer Program,

- Implementation of the Evacuation and Shelter-In-Place program, and

- Preparation of institutional emergency plans, procedures, and hazard assessments.

LLNL maintains a fire station at Site 200. LLNL's Fire Department has the primary responsibility for providing Site 200 with fire, rescue, hazardous material response, and emergency services. Memoranda of Understanding exist with several community agencies, including the Alameda County, Livermore/Pleasanton, and Tracy Fire Departments, Valley Care and Eden Medical Centers, and local governments. These Memoranda of Understanding include notification of, and coordination with local authorities.

LLNL operates and manages the Alameda County Regional Emergency Communication Center (911) which presently dispatches for 41 fire stations and 6 agencies, and is responsible within Alameda County for the coordination of fire and mutual aid, as well as emergency medical dispatch and ambulance transport coordination.

\section{F. Planned Changes to Improve Safety}

Existing review indicates that these safety provisions are adequate. Therefore, there are no planned changes beyond continued implementation of the continuous improvement process in place at LLNL. 